\title{
On the discovery of tetrapod trackways from Permo-Carboniferous redbeds of Prince Edward Island and their biostratigraphic significance
}

\author{
John H. CAldeR ${ }^{1 *}$, Donald Baird ${ }^{2 \S}$, And Elliott B. Urdang 3 \\ 1. Nova Scotia Department of Natural Resources, P.O. Box 698, Halifax, NS, Canada B3J 2T9 <jhcalder@gov.ns.ca> \\ 2. Museum of Natural History, Princeton University, Princeton, New Jersey 08544, USA \\ 3. 57 Dana Street, Providence, Rhode Island 02906, USA <penrhyn854@aol.com> \\ * Corresponding author \\ Present address: 4 Ellsworth Terrace, Pittsburgh, Pennsylvania 15213, USA.
}

Date received January 7,2004 Date accepted September 28, 2004

\begin{abstract}
The first fossil tetrapod footprints that were discovered on Prince Edward Island, and which were previously undescribed, are small reptilian trackways assignable to the ichnogenera Notalacerta and Gilmoreichnus. Their closest zoological correlatives are small, Permo-Carboniferous "stem-reptiles" of the families Protorothyrididae and Captorhinidae in the suborder Captorhinomorpha, and pelycosauran reptiles, possibly of the Ophiacodontidae. Reptiles of this type are rare to unrepresented in the skeletal fauna of the province. The biochronology of the track-bearing bed, combined with terrestrial vertebrate, palynological and macrofloral records, suggest that the host Pictou Group redbeds on Prince Edward Island young from late Stephanian (Pennsylvanian) at Malpeque Bay to early Permian in the north. The combined discoveries of tetrapod footprints and trackways from these Permo-Carboniferous redbeds suggests that the record is potentially extensive. Now included in this record is the youngest known occurrence of the ichnogenus Notalacerta.
\end{abstract}

\section{RÉSUMÉ}

Les premières empreintes de fossiles de tétrapodes découvertes sur l'île-du-Prince-Édouard, et précédemment non décrites, sont des traces d'un petit reptile qu'on peut rattacher aux ichnogenres Notalacerta et Gilmoreichnus. Leurs parents géologiques les plus proches sont les petits " reptiles-tiges » permocarbonifères des familles des protorothyridides et des captorhinides du sous-ordre des captorhinomorphes, ainsi que les reptiles pélicosauriens, possiblement les ophiacodontides. Les reptiles de ce type sont rares sinon absents au sein de la faune squelettique de la province. La biochronologie des strates renfermant des traces conjuguée aux relevés de vertébrés terrestres et aux relevés palynologiques et macrofloraux laisse supposer que les couches rouges hôtes du groupe de Pictou, sur l'Île-du-Prince-Édouard, remontent à la période du Stéphanien tardif(Pennsylvanien), dans la baie Malpeque, au Permien précoce, dans le nord. Les découvertes combinées d'empreintes et de traces de tétrapodes des couches rouges permocarbonifères semblent indiquer que la quantité d'enregistrements pourrait être vaste. Ces enregistrements comprennent désormais la manifestation la plus récente connue de l'ichnogenre Notalacerta.

[Traduit par la rédaction.] 


\section{INTRODUCTION}

Fossil footprints of vertebrates are known in remarkable quantity and diversity from many stratigraphic levels in the Mississippian and Pennsylvanian of the Maritimes Basin in Nova Scotia (Dawson 1855 and supplements; Matthew 1903, 1905; Carroll et al. 1972; Sarjeant and Mossman 1978; Calder et al. 1995). In marked contrast, none had been described from the neighbouring province of Prince Edward Island nor from the Permian of the Maritimes Basin previous to the discovery in 1984 of the footprints reported here. Since the discovery of trackways described here, a subsequent discovery from Prince Edward Island was published by Mossman and Place (1989). The small but prolific trackway-bearing slab here described was discovered at Beech Point, Malpeque Bay by EBU in August of 1984. When the significance of the find had been confirmed by Dr. John Ostrom of Yale University (written communication, 25 March 1987), he revisited the site in 1987 and in subsequent years collected additional, isolated footprints of the same types with Mr. Charles Corkum of Prince Edward Island.

\section{LOCATION}

The fossil locality is situated on the eastern shore of Malpeque Bay at Beech Point, north of the end of Beech Point Road and due west of the town of Hamilton, in GSC Map Area 11L5 at latitude $46^{\circ} 29^{\prime} 40^{\prime \prime}$ north, longitude $63^{\circ} 45^{\prime}$ west (Fig. 1). The tracks occur as natural casts within redbeds of the Hillsborough River Formation (van de Poll 1989). The trackway-bearing horizon occurs as a locally reduced, pale grey sandstone horizon within a sequence of tabular, reddish

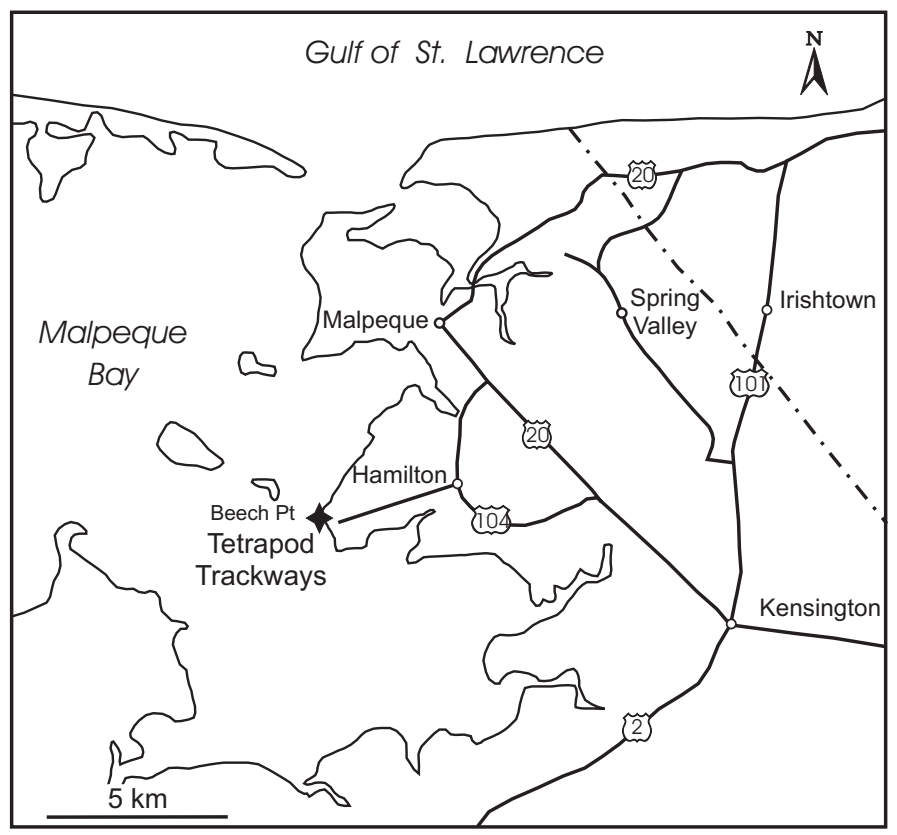

Fig. 1 Map of the eastern Malpeque Bay area, showing location of the Beech Point trackway site. brown sandstone beds with internal large-scale, shallow crosssets and less commonly, narrow troughs (Fig. 2). Greenish-grey mottling occurs on bedding surfaces and vertically. The shore there is covered with a shingle of flat, somewhat water-worn, sandstone cobbles and boulders derived from the typical red bluffs along the beach.

\section{DESCRIPTION OF MATERIAL}

Small slab (Figs. 3, 5, 6) with natural casts of three or more partial trackways; three isolated pedal imprints (Fig. 4). Originals in the possession of EBU; casts reside in the National Museum of Natural Sciences, Ottawa, the Nova Scotia Museum of Natural History (NSM 988GF72.1), and the Peabody Museum of Yale University (YPM-PU 23973).

Trackway A comprises a left manus-pes set and the following right pes print. (The isolated pes is identical to A in size and form.) Trackway B was made by an individual about threefourths the linear size of A. It begins with a right manus-pes set; the following left set is partly obscured; and the second right pes, truncated by the slab edge, overprints the third and fourth toes of the right pes in Trackway A. No tail-trace is evident. Measurements are given in Table 1.

\section{SYSTEMATIC ICHNOLOGY}

\section{Ichnogenus Gilmoreichnus Haubold, 1971 \\ Gilmoreichnus cf. G. (Hylopus) hermitanus (Gilmore, 1927) Trackway 'A' (Fig. 5)}

Description: Manus and pes are of similar proportions, both pentadactyl, with digits increasing in length from I to IV, and digit $\mathrm{V}$ somewhat offset. In deep impressions, the pes shows an oval sole extending posterolaterally. Inter-phalangeal joints are indicated by swellings: the phalangeal formula is evidently

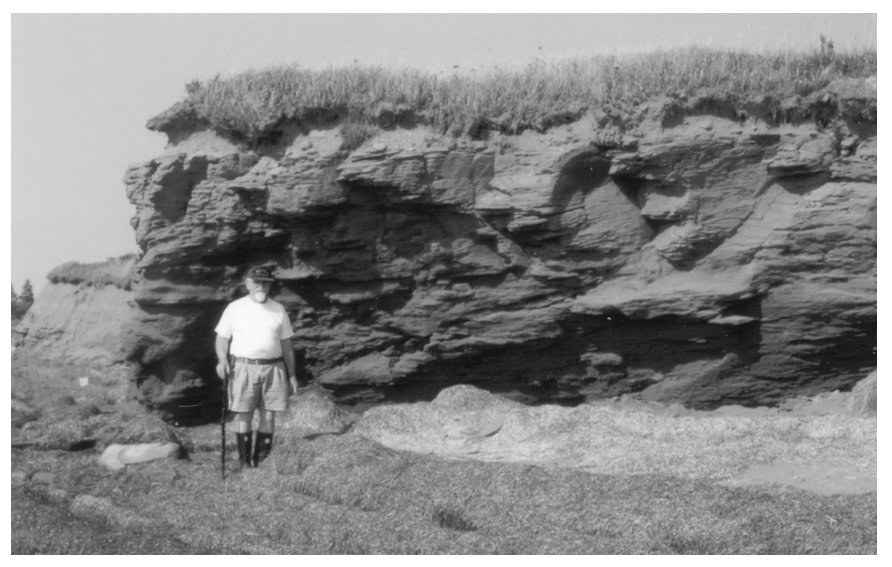

Fig. 2 Trackway-bearing sandstone of the Hillsborough Bay Formation outcropping at Beech Point, Malpeque Bay, with the discoverer, E.B. Urdang. 


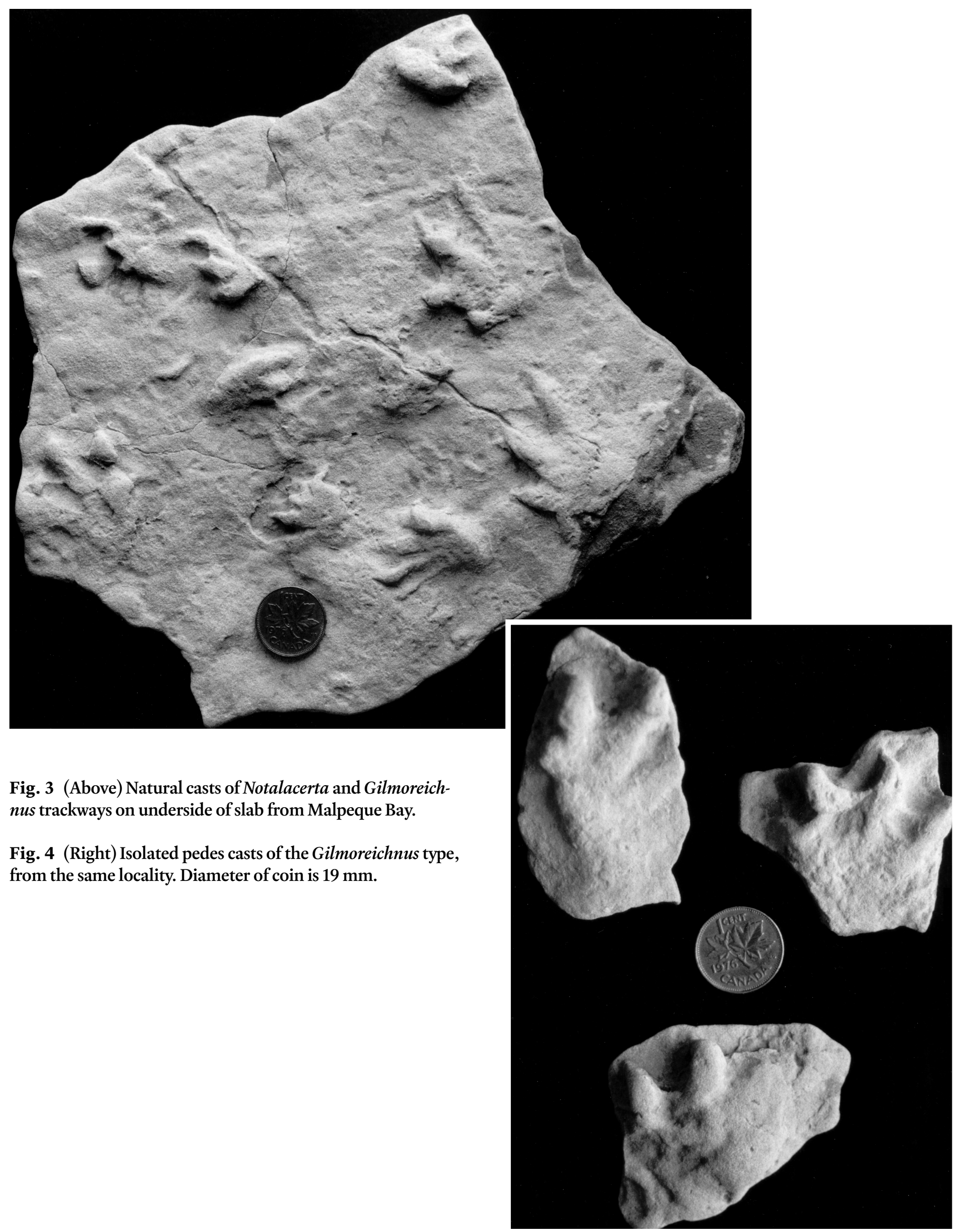




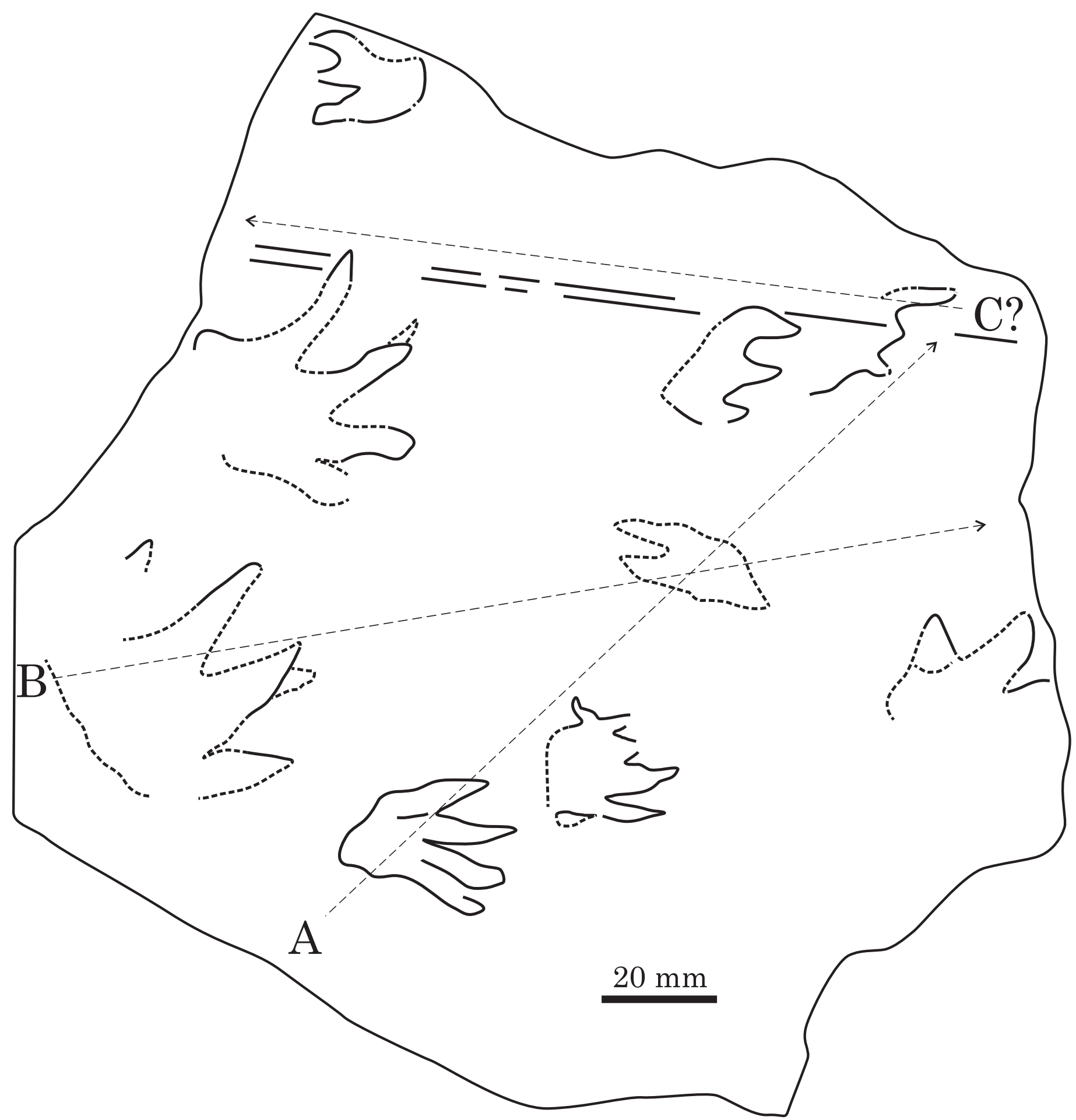

Fig. 5 Diagram of tracked surface (reversed from Fig. 3 to represent original trackway impression) showing principal Gilmoreichnus (A) and Notalacerta trackways (B). A tentative third trackway (?C) of a small tetrapod, is indicated by poorly preserved prints and a possible tail drag. Diameter of circle is $19 \mathrm{~mm}$. 
Table 1. Trackway measurements, in millimetres; asterisk (*) indicates estimates made by extrapolation.

\begin{tabular}{lcc}
\hline & Trackway A & Trackway B \\
Manus $(1 \times w)$ & $36 \times 40$ & $22 \times 20$ \\
Pes (l w w) & $43 \times 48$ & $31 \times 22$ \\
Pace between centres of pedes & 126 & 88,82 \\
Stride & $156^{*}$ & 110 \\
Pace angulation & $78^{\circ *}$ & $74^{\circ}$ \\
Gleno-acetabular trunk length of trackmaker & $130^{*}$ & $90^{*}$ \\
Trackway width (interpes) & $100^{*}$ & $65^{*}$ \\
\hline
\end{tabular}

the primitive reptilian one of 2-3-4-5-3 (manus) and 2-3-4-5-4 (pes). Short, pointed claws are apparent. The manus and pes show little divarcation from the midline of the trackway.

Remarks: The ichnogenus Gilmoreichnus was erected by Haubold for specimens previously assigned in part to the ichnogenera Brachydactylichnia Pabst, 1900, Ichnium Pabst, 1900 and Hylopus Gilmore, 1927. Gilmoreichnus has been widely reported from the Lower Permian of southwestern North America: the Hermit Shale, Grand Canyon and the middle Earp Formation, Big Hatchet Mountains, New Mexico (Baird, in Zeller 1965) and from extensive collections from the Robledo Mountains of New Mexico (Haubold et al. 1995). In eastern North America, Gilmoreichnus is known from southeastern Prince Edward Island and from Brule, in northern Nova Scotia.

The footprints assigned to trackway ' $\mathrm{A}$ ' most closely resemble Gilmoreichnus (Hylopus) hermitanus (Gilmore, 1927), as described by Haubold et al. (1995, their figs. 17-22), from the Robledo Mountains of New Mexico, and in particular, the holotype of G. hermitanus (Haubold et al. 1995, their fig. 17B, p. 156.) A more diminutive ichnospecies, Gilmoreichnus kablikae Haubold, 1974 has been described by Mossman and Place (1989) from Prim Point, Prince Edward Island (Fig. 7) in redbeds mapped as the Kildares Cape Formation (Mossman and Place 1989). This ichnotaxon occurs as well at the walchian conifer and vertebrate trackway site at Brule, northern Nova Scotia (Fig. 7), within redbeds of the Cape John Formation (Calder et al. 1995; unpublished materials). We also note the possible alternative identification of footprints assigned by Mossman and Place to Ichniotherium cf. I. willsi Haubold and Sarjeant, 1973 as an ichnospecies of Gilmoreichnus $(\mathrm{H}$. Haubold, referenced in Mossman and Place (1989)).

\section{Ichnogenus Notalacerta Butts, 1891 Notalacerta isp. \\ Trackway 'B'(Fig. 5)}

Description: Manus and pes both pentadactyl, with the pes imprint somewhat more elongate (possibly exaggerated by toe dragging). Digits increasing in length from I to IV, and digit V somewhat offset. In deep impressions, the pes shows an oval
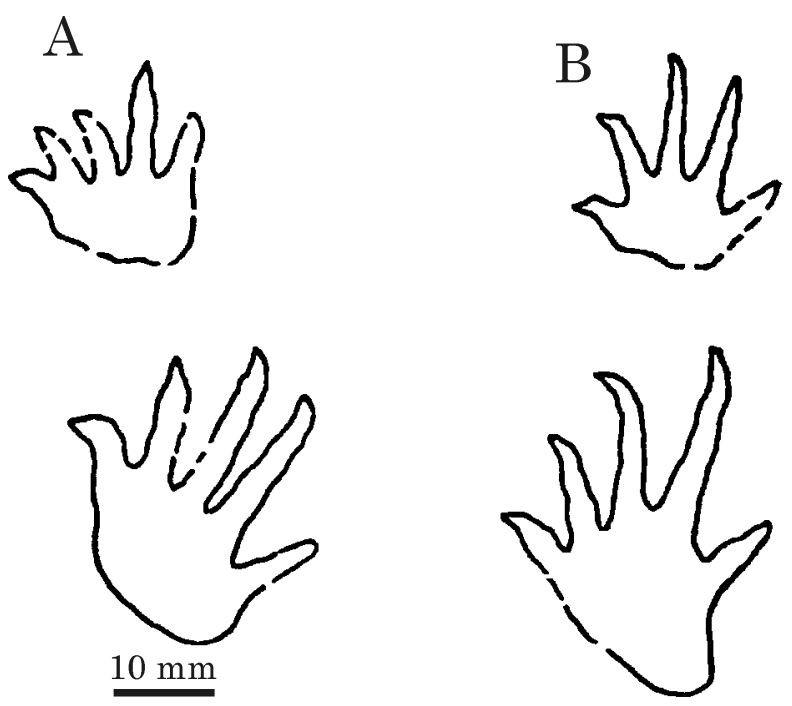

Fig. 6 A. right manus-pes set of Notalacerta sp. from Malpeque Bay, Prince Edward Island as drawn by DB. B. $N$. missouriensis from Kansas City, MO (composite from topotypes and photographs of types). Scale bar $=1 \mathrm{~cm}$.

sole extending posterolaterally. Inter-phalangeal joints are indicated in some digits by swellings: the phalangeal formula appears to be of the primitive reptilian one of 2-3-4-5-3 (manus) and 2-3-4-5-4 (pes). Short, pointed claws are apparent in some impressions, but the form of the toe-tips tends to be obscured by dragging as the feet lifted off in the recovery phase of the stride. The pes is more out-turned than the manus, with its digit II nearly parallel to the trackway midline.

Remarks: The ichnogenus Notalacerta, type species N. missouriensis, was described by Butts (1891) from beds above the Cement City Limestone (Stephanian: Missourian, Upper Pennsylvanian) of Kansas City, Missouri, with a brief but adequate diagnosis and an illustration drawn by the collector, Sid J. Hare. Butt's type specimens are now unlocated, but good contemporary photographs of them are included in the 


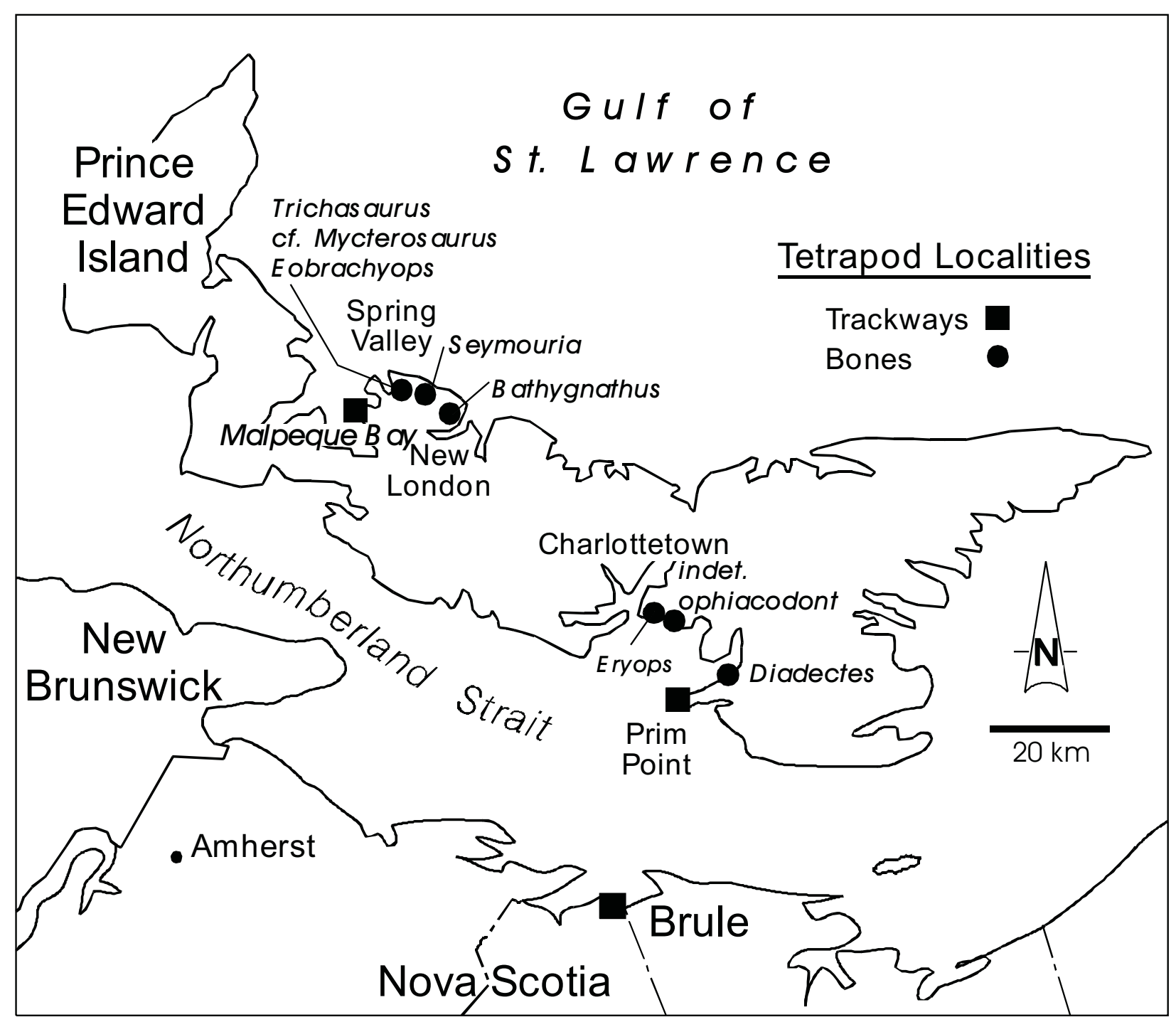

Fig. 7 Permo-Carboniferous vertebrate fossil localities and trackway sites on Prince Edward Island and the northern mainland of Nova Scotia. Vertebrate taxa and localities from Langston 1963; Prim Point trackway locality from Mossman and Place 1989.

Hare Album that is now housed in the Springer Room at the National Museum of Natural History (Baird 1982). Topotypic specimens are preserved at several institutions, including the National Museum of Natural History (USNM 7321), the Museum of Comparative Zoology at Harvard College (MCZ 204, 205, 206), and the Museum of Palaeontology, University of Michigan (Fig. 6B).

The earliest record of Notalacerta is an excellent long trackway from the Rockcastle Sandstone Member of the Lee Formation (Westphalian A, Lower Pennsylvanian) near Somerset, Kentucky (Lewis 1973; Chesnut et al. 1994). Several fine trackways also occur in association with the classic vertebrate fauna of Garnett, Kansas, in the Rock Lake Shale Member of the Stanton Formation (Stephanian: Missourian, Upper Pennsylvanian; Gaebel and Baird, in prep.). These specimens bear a close resemblance to the Missouri material, as well as to that from Prince Edward Island. For example, the posterolat- eral heel seen in Fig. 3 is not apparent in Butt's illustration but is clearly shown in a syntype trackway in Hare's photographs, and also in the two trackways on Garnett slab ER0015 in the Erindale College collection. Expression of the tail-trace is variable in Notalacerta trackways, as in all Paleozoic tetrapod tracks (A. Hunt, personal communication, 2004). In Butt's syntypes of N. missouriensis, it is continuous in one deeply-impressed trail, but absent from shallower ones (his illustration is a composite of the two types). A tail-trace is present but intermittent in the Kentucky trackway, absent or intermittent in the Kansas material, and absent on the slab from Prince Edward Island. Although the new Canadian specimen represented by trackway B is assignable to Notalacerta at the ichnogeneric level, additional material will be required before ichnospecific differentiation can be attempted.

The Notalacerta tracks share several morphological features with the lacertoide Permian ichnogenera Dromopus Marsh, 
1894 and especially Varanopus Moodie, 1929, including lacertoid morphology, pentadactyl manus and pes, and similar increase in length of digits I through IV (Haubold 1971; Haubold and Lucas 2001). Dromopus is the most distinctive of the three, with morphological differences that include a much wider interdigital angle for IV-V and more pronounced lengthening and curvature of digits I through IV (Haubold 1971, cf. figs. 13.14, 18.1-5 and 19.1-2). The morphological similarities betwen Notalacerta and Varanopus are subtle, however, and future work is needed to clarify the relationship of these two ichnogenera especially in light of the relatively scant fossil record of Notalacerta. It is uncertain if the more pronounced inter-phalangeal joints indicated in Dromopus and Varanopus reflect osteological differences in the trackmakers or preservational variation in Notalacerta, but they are present in all type specimens of Dromopus (Haubold 1971, figs. 18.1-5) and Varanopus (Haubold 1971, figs. 19.1-2).

\section{DISCUSSION}

The assignment of trackway A to Gilmoreichnus and trackway B to Notalacerta is consistent with the summary descriptions of the ichnogenera in the treatise of Haubold (1971, cf. his figs. 13.14 and 20.1,2). Amongst the attributes that differentiate these two ichnogenera, Notalacerta differs from Gilmoreichnus in its lacertoid morphology and smaller size. A possible third trackway ' $\mathrm{C}$ ' with poorly preserved footprints and medial, straight tail drag is of uncertain affinity.

The number of trackways on one small slab indicates concentrated activity at this horizon, which bodes well for future discoveries. The occurrence of such a concentrated footprint record within a reduced redbed horizon is suggestive of the presence of organic material, but whether organic matter in the presence of the trackmakers bears any paleoecological significance is uncertain. A trackway site in coeval redbeds of the Pictou Group at Brule, Nova Scotia (Calder et al. 1995; unpublished material) occurs within a walchian conifer forest interpreted to be a dryland waterhole.

\section{ZOOLOGICAL AFFINITY}

In comparing Paleozoic trackways with taxa based on skeletal material, we are hampered by the fact that, in most of the latter, the feet are unknown. Whole groups of animals must therefore be omitted from comparison for lack of evidence. Even in those taxa for which foot material is known, it is seldom complete enough to permit a strictly factual reconstruction of both manus and pes. Our attempts at correlation will therefore be, at best, approximations.

The foot structure represented in the Malpeque Bay footprints is of a primitive reptilian type. Eliminating, therefore, the various Permo-Carboniferous amphibian groups and those reptiles with more specialized feet, our attention logically focuses on the small, generalized "stem-reptiles" of the Suborder
Captorhinomorpha, the group that appears to have given rise to all the more advanced reptiles and thus, indirectly, to birds and mammals. Following Heaton (1979), the more primitive Pennsylvanian and early Permian captorhinomorphs constitute the Protorothyrididae ("Romeriidae" of other authors), while the more derived genera from the early Permian constitute the Captorhinidae, with the captorhinid Romeria providing a morphological transition between the two families. What is known of their foot structure is described for Carboniferous forms by Carroll and Baird (1972) and for Permian ones by Clark and Carroll (1973) and Holmes (1977). The body proportions of these reptiles are similar to those deduced for the Notalacerta and Gilmoreichnus trackmakers, and a close correspondence in the skeletal structure and proportions of the manus and pes is evident. Trackmaker ' $\mathrm{B}$ ' evidently was a moderately shortbodied animal that walked with a sprawling gait. Trackmaker 'A', however, appears to have had a more elevated posture and less sprawling gait.

We are not prepared to nominate any particular genus as the closest correlative of the Prince Edward Island trackmakers. Haubold (1971) ascribed Notalacerta to the temnospondyl amphibians; however, we feel that the attributes described above are inconsistent with that group. The strong affinity of Gilmoreichnus with pelycosaurs such as Ophiacodon (Haubold 1971), the osteological remains of which have been reported from the Pictou Group redbeds of Prince Edward Island (Langston 1963), we consider more tenable. Prince Edward Island redbeds have provided a fossil record of large vertebrate taxa (Fig. 7) including eryopoid and brachyopoid temnospondyl amphibians, the problematic reptiliomorphs Seymouria and Diadectes, and reptiles that include ophiacodont, sphenacodont and edaphosaur pelycosaurs (Langston 1963). Up to now, however, no bones of primitive captorhinomorphs have been identified. This is hardly surprising, for small reptiles are relatively uncommon, even in the more abundantly fossiliferous beds of the Ohio Valley and the New Mexico-TexasOklahoma area. In Atlantic Canada, despite energetic and extensive prospecting by Langston and his colleagues, the Permian redbeds of Prince Edward Island have so far yielded only half-a-dozen fragmentary specimens of reptiles. Thus, the footprints from Malpeque Bay serve as still another example of how the ichnological evidence can supplement the skeletal record to provide a fuller understanding of an ancient fauna.

\section{BIOCHRONOLOGY}

The footprints of Malpeque Bay are broadly PermoCarboniferous in morphology but include ichnogenera that if discovered in isolation from one another would be taken to indicate either a Pennsylvanian (Notalacerta) or early Permian (Gilmoreichnus) age (Lucas 2002a, 2003). The youngest occurrence known previously of Notalacerta is from the Stephanian of the western United States, and the oldest occurrence known of Gilmoreichnus dates from the late Stephanian of western Europe (Lucas 2003). The ichnological record there- 
fore coincides most parsimoniously with the late Stephanian Dromopus biochron of Lucas (2003). Although the ichnogenus Notalacerta is represented in this biochron, the Malpeque Bay locality represents its youngest known occurrence, which conservatively is late Stephanian: the palynological and macrofloral records of the redbeds of Malpeque Bay place them in the late Stephanian to Lower Permian, whereas the osteological record of vertebrates favours a Lower Permian age.

Frankel and Crowl (1970) and Prest (1972) assigned outcrops in the region of Spring Valley (Fig. 7, between Malpeque Bay and New London Bay) to the informally named stratigraphic Subunit A2, which they assigned to the Lower Permian on paleontological evidence. Subsequent lithostratigraphic study by van de Poll (1983) assigned the strata, in which the footprints of Malpeque Bay and Prim Point (Fig. 7) both occur, to his informal Megacyclic Sequence III of the Pictou Group. More recently, van de Poll (1989) introduced formal lithostratigraphic nomenclature for the redbed outcrops on PEI, and in so doing he renamed the unit in which the track-bearing sequence occurs, the Hillsborough River Formation. The correlation of the formations of van de Poll with those in informal use for the subsurface geology of the Gulf of St. Lawrence (Rehill et al. 1995; Giles and Utting 1999) is somewhat problematic. Petroleum wells in the area have been interpreted as being collared in the Naufrage Formation (Giles and Utting 1999), although a direct correlation of the two formational schemes awaits. The age of the Hillsborough River Formation was given by van de Poll (1989) as early Permian (Artinskian).

The southeastern district of Prince Edward Island, in the area around Hillsborough Bay (Fig. 7), yields a spore flora identified by Barss et al. (1963) that agrees with the amphibians and reptiles described by Langston (1963) in indicating an early Permian age for the fossiliferous beds. In the northcentral district around Malpeque Bay, however, the two disciplines appear to yield discordant ages. The uppermost strata of borehole Imperial MacDougall No. 1, situated west of Malpeque Bay were dated by Barss et al. (1963) as Stephanian (late Pennsylvanian) on the basis of palynology. (In boreholes north and south of it, however, Stephanian spore assemblages were not encountered above the $524 \mathrm{~m}$ level.) The most recent interpretation of the age of these strata, which have been assigned to the Naufrage Formation (Giles and Utting 1999), is Stephanian to early Permian based on a Stephanian palynoflora from well samples and inferences of a younger age for overlying, barren redbeds, in part drawn from the vertebrate record discussed below (P.S. Giles, personal communication, 2001). Recently, Ziegler et al. (2002) have undertaken an assessment of the macrofloral record of the Prince Edward Island redbeds in an effort to resolve local phytogeographic effects from global climate change accompanying the fall in global sea level during the early Permian. Their assessment of the combined paleontological data for Prince Edward Island supports a Stephanian-Lower Permian age range for the redbeds, with a general younging to the northeast, as purported by van de Poll (1989).

East of Malpeque Bay are two bone-bearing sites, Spring
Valley (P-6108) and Irishtown (P-6111), from which vertebrate fossils were described by Langston (1963). A review of osteological finds and their biostratigraphic significance follows.

\section{Spring Valley}

(1) A partial skull and mandible of a trimerorhachoid amphibian comparable to Saurerpeton and particularly to "Eobrachyops" (= Isodectes). The family Saurerpetontidae, to which these genera belong, ranges from middle Pennsylvanian (Westphalian D) to Lower Permian. Although Isodectes was known only from the Arroyo Formation of Texas (Leonardian, Lower Permian) at the time Langston analyzed his data, it has since been found in the Upper Pennsylvanian (Virgilian) of Kansas (Baird 1966; Chorn and Conley 1978). Thus, the Spring Valley amphibian does not help to refine the dating. (2) A mandible most closely comparable to the pelycosaurian reptile Mycterosaurus, a genus known from the Leonardian of Texas. (3) A metatarsal possibly of Trichasaurus, a caseid pelycosaur from the Leonardian of Texas. These faunas are consistent with land-vertebrate faunachron C of Lucas (2002b), correlative with the Upper Rotliegend of the early Permian.

\section{Irishtown}

A partial femur of the advanced anthracosaurian amphibian Seymouria, a genus that ranges through several formations in the Wolfcampian and Leonardian (early Permian) of Texas. The presence of Seymouria would place these beds no older than faunachron B of Lucas (2002b), coeval with the Tambach Formation of the Upper Rotliegend.

\section{Summary}

The combined biostratigraphic evidence agree in a late Stephainian-early Permian age for the Hillsborough River Formation at Malpeque Bay. Palynological, macrofloral and tetrapod ichnological data concur with a late Stephanian age, whereas the osteological record of tetrapods suggests a younger, early Permian age. It is improbable, however, based on the combined evidence and in particular the occurrence of Notalacerta, that these strata are as young as Artinskian.

\section{CONCLUSIONS}

Vertebrate trackway and skeletal discoveries from the redbeds of the Maritimes Basin exposed on Prince Edward Island, together with macrofloral evidence framed by subsurface palynology, increasingly agree in a late Stephanian to early Permian age for the redbeds of Prince Edward Island. The combined biostratigraphic data indicate an age of late Stephanian at Malpeque Bay, younging northward through early Permian. Reflected in the fossil record is the global rise to dominance of terrestrially adapted tetrapods during the Permian as continental conditions and moisture deficits became widespread 
across the paleoequatorial regions of Pangea. The first records of Notalacerta and Gilmoreichnus from Prince Edward Island, combined with the subsequent discovery of Mossman and Place (1989), reflects the high probability that these redbeds are the repository of a significantly more extensive vertebrate trackway record than previously recognized. The youngest known occurrence of Notalacerta emphasizes the significance of this record.

\section{ACKNOWLEDGEMENTS}

The field assistance of Dr. Peter Kosseff of Newport, R.I., and Charles Corkum of Summerside, Prince Edward Island, is warmly acknowledged. Rubber molds of the Kansas and Kentucky trackways of Notalacerta were kindly supplied by Kathryn A. Gaebel and Richard C. Lewis, respectively. N. Gary Lane discovered and loaned, for photocopying, the Sid J. Hare Album of Missouri fossils. We thank Wann Langston, Jr., and the late William A.S. Sarjeant for their critical reading of an early version of the manuscript, to Bob Ryan, Adrian Hunt, and Spencer Lucas for their constructive criticisms and finally David J.W. Piper for bringing the manuscript to the attention of JHC and encouraging its publication. The research of DB was supported by the William Berryman Scott Fund of Princeton University.

\section{REFERENCES}

BAIRD, D. 1966. New labyrinthodont amphibian from the Pennsylvanian of Kansas. Geological Society of America, Special Paper, 101, pp. 8-9.

BaIRD, D. 1982. Upper Pennsylvanian ichnology of Kansas City, Missouri. Ichnology Newsletter, 13, p. 11.

Barss, M.S., Hacquebard, P.A., \& Howie, R.D. 1963. Palynology and stratigraphy of some Upper Pennsylvanian and Permian rocks of the Maritime Provinces. Geological Survey of Canada, Paper 63-3, pp. 1-13.

ButTs, E. 1891. Recently discovered foot-prints of the Amphibian Age, in the Upper Coal Measure Group of Kansas City, Missouri. Kansas City Scientist, 5, pp. 17-19.

Calder, J.H., Van Allen, H.E.K., Adams, K.G., \& Grantham, R.G. 1995. Tetrapod trackways in a fossil Walchia forest: a new discovery from the early Permian of Nova Scotia. Atlantic Geology, 31, p. 42.

Carroll, R.L., \& BaIRd, D. 1972. Carboniferous stem-reptiles of the family Romeriidae. Harvard Museum of Comparative Zoology Bulletin, 143, pp. 321-364.

Carroll, R.L., Belt, E.S., Dineley, D.L., Baird, D., \& McGregor, D.C. 1972. Field excursion A59, vertebrate palaeontology of eastern Canada. Guidebook, 24th International Geological Congress, $113 \mathrm{p}$.

Chesnut, D.R., Baird, D., Smith, J.H., \& Lewis, R.Q. 1994. Reptile trackway from the Lee Formation (Lower Pennsyl- vanian) of south-central Kentucky. Journal of Paleontology, 68, pp. 154-158.

Chorn, J., \& Conley, C.D. 1978. A Late Pennsylvanian vertebrate assemblage in the Bern Limestone, northeastern Kansas. Kansas Academy of Science Transactions, 81, p. 139.

Clark, J.B., \& CARROLL, R.L. 1973. Romeriid reptiles from the Lower Permian. Harvard Museum of Comparative Zoology Bulletin, 144, pp. 353-407.

DAwson, J.W. 1855 (and Supplements, 1868, 1878, 1891). The Geology of Nova Scotia, New Brunswick and Prince Edward Island or Acadian Geology. Oliver and Boyd, Edinburgh, $694 \mathrm{p}$.

Frankel, L., \& Crowl, G.H. 1970. Permo-Carboniferous stratigraphy and structure of central Prince Edward Island. Geological Survey of Canada, Paper 69-17, pp. 1-26.

GAEBEL, K.A., \& BAIRD, D. (in prep.) Tetrapod trackways from the Upper Pennsylvanian Rock Lake Member, Stanton Formation, near Garnett, Anderson County, Kansas.

Giles, P.S., \& Utting, J. 1999. Maritimes Basin stratigraphy: Prince Edward Island and adjacent Gulf of St. Lawrence. Geological Survey of Canada, Open File 3732.

Gilmore, C.W. 1927. Fossil footprints from the Grand Canyon: second contribution. Smithsonian Miscellaneous Collections, $80,78 \mathrm{p}$.

Haubold, H. 1971. Ichnia Amphiborum et Reptiliorum fossilium. Encyclopedia of Palaeoherpetology, 18, Gustav Fischer Verlag, Stuttgart, $124 \mathrm{p}$.

Haubold, H. 1974. Die Fossilium Saurierfährten. A. Ziemsen Verlag, Wittenberg-Lutherstadt, GDR, 168 p.

Haubold, H., \& Lucas, S.G. 2001. Die tetrapodfährten der Choza Formation (Texas) und das Artinsk-Alter der Redbed-Ichnofaunen des Unteren Perm. Hallesches Jahrbuch Geowissenschaften, B23, pp. 79-108.

Haubold, H., \& SarJeant, W.A.S. 1973. Tetrapodenfährten aus den Keele und Enville Groups (Permokarbon: Stefan und Autun) von Shropshire und South Staffordshire, Grossbritannien. Zeitschrift Geologische Wissenschaften, 1, pp. 895-933.

Haubold, H., Hunt, A.P., Lucas, S.G., \& Lockley, M.G. 1995. Wolfcampian (Early Permian) vertebrate tracks from Arizona and New Mexico. In Early Permian Footprints and Facies. Edited by S.G. Lucas \& A.B. Heckert. New Mexico Museum of Natural History and Science Bulletin No. 6, pp. 135-165.

HeAton, M.J. 1979. Cranial anatomy of primitive captorhinid reptiles from the Late Pennsylvanian and Early Permian, Oklahoma and Kansas. Oklahoma Geological Survey Bulletin, 127, pp. 1-84.

Holmes, R. 1977. The osteology and musculature of the pectoral limb of small captorhinids. Journal of Morphology, 152, pp. 101-140.

Langston, W., Jr. 1963. Fossil vertebrates and the Late Palaeozoic red beds of Prince Edward Island. National Museum of Canada, Bulletin 187, 36 p.

LEWIS, R.Q. 1973. Pennsylvanian reptile in Kentucky? United States Geological Survey, The Cross Section, 4, pp. 6-7. 
Lucas, S.G. 2002a. Global Permian tetrapod footprint biostratigraphy and biochronology. Permophiles, 41, 30-34.

Lucas, S.G. 2002b. Tetrapods and the subdivision of Permian time. In Carboniferous and Permian of the World, XIV ICCP Proceedings. Edited by L.V. Hills, C.M. Henderson \& E.W. Bamber. Canadian Society of Petroleum Geologists, Memoir 19, pp. 479-491.

LuCAS, S.G. 2003. Carboniferous tetrapod footprint biostratigraphy and biochronology. Carboniferous Newsletter, July, pp. 36-41.

MARSH, O.C. 1894. Footprints of vertebrates in the coal measures of Kansas. American Journal of Science, 48, pp. 81-84.

Matthew, G.F. 1903. On batrachian and other footprints from the Coal Measures of Joggins, N.S. Natural History Society of New Brunswick, Bulletin 21, pp. 103-108.

Matthew, G.F. 1905. New species and a new genus of batrachian footprints of the Carboniferous system in Eastern Canada. Royal Society of Canada, Proceedings and Transactions, 10, pp. 77-121.

Moodie, R.L. 1929. Vertebrate footprints from the redbeds of Texas. American Journal of Science, 17, pp. 352-368.

Mossman, D.J., \& Place, C.H. 1989. Early Permian fossil vertebrate footprints and their stratigraphic setting in megacyclic sequence II red beds, Prim Point, Prince Edward Island. Canadian Journal of Earth Sciences, 26, pp. 591-605.

PABst, W. 1900. Beiträge zur Kenntnis der Tierfährten in dem Rotliegenden Deutschlands. Zeitschrift der Deutschen Geologischen Gesellschaft, 52, pp. 48-63.
Prest, V.K. 1972. Geology of Malpeque-Summerside area, Prince Edward Island. Geological Survey of Canada, Paper 71-45, pp. 1-21.

Rehill, T.A., Gibling, M.R., \& Williamson, M.A. 1995. Stratigraphy of the Central Maritimes Basin, eastern Canada: non-marine sequence stratigraphy. Geological Survey of Canada, Current Research 1995-E, pp. 221-231.

SarJeAnt, W.A.S., \& Mossman, D.J. 1978. Vertebrate footprints from the Carboniferous sediments of Nova Scotia: an historical review and description of newly discovered forms. Palaeogeography, Palaeoclimatology, Palaeoecology, 23, pp. 279-306.

van De Poll, H.W. 1983. Geology of Prince Edward Island. Prince Edward Island Department of Energy and Forestry Report 83-1, $66 \mathrm{p}$.

VAN DE Poll, H.W. 1989. Lithostratigraphy of the Prince Edward Island redbeds. Atlantic Geology, 25, pp. 23-35.

Zeller, R. 1965. Stratigraphy of the Big Hatchet Mountains Area. New Mexico Bureau of Mines and Mineral Resources, Memoir 16, 48 p.

Ziegler, A.M., Rees, P. Mca., \& Naugolnykh, S.V. 2002. The Early Permian floras of Prince Edward Island, Canada: differentiating global from local effects of climate change. Canadian Journal of Earth Sciences, 39, pp. 223-238.

Editorial responsibility: Ron K. Pickerill 